\title{
BEATING BROKE BY GETTING OUT? EXAMINING THE RELATIONSHIP BETWEEN PERSONAL DEBT AND COMMUNITY OUTMIGRATION
}

\begin{abstract}
Alyssa Gerhardt and Karen Foster
Abstract: Scholarship on young people's geographical mobilities tells us that young adults move away from their childhood communities for a complex mix of economic "push-pull" reasons, including relationships, aspirations, attachments to place, identity, and belonging. In this abundant research, particularly that which focuses on youth outmigration from rural and peripheral communities, there is surprisingly little attention paid to an issue that is top-of-mind for many young adults today: personal debt. In this paper, we draw insights from extant literature on youth mobilities to make the case for a greater examination of the role of personal debt in young people's migration decisions. We hypothesize that youth and debt increase a person's likelihood of moving away from peripheral regions. We test this hypothesis using data from a 2019 survey of Atlantic Canadians and find some support for it, and some interesting nuance, suggesting that there is good reason to examine debt's role in youth mobilities in greater detail.
\end{abstract}

Keywords: community, outmigration, personal debt, Atlantic Canada, mobilities, youth

Acknowledgement: This paper draws on research supported by Social Sciences and Humanities Research Council.

Alyssa Gerhardt MA (corresponding author) is a doctoral student in the Department of Sociology and Social Anthropology, Dalhousie University, Rm. 1128, Marion McCain Arts and Social Sciences Building, 6135 University Ave., Halifax, NS B3H 4R2.

Email: alyssa.k.gerhardt@dal.ca

Karen Foster $\mathrm{PhD}$ is an associate professor of Sociology, Canada Research Chair in Sustainable Rural Futures for Atlantic Canada, and director of the Rural Futures Research Centre at Dalhousie University, Rm. 1128, Marion McCain Arts and Social Sciences Building, 6135 University Ave., Halifax, NS B3H 4R2. Email: karen.foster@,dal.ca 
International Journal of Child, Youth and Family Studies (2021) 12(2): 25-47

Youth outmigration can be a pressing policy concern wherever populations are shrinking, aging, or not growing "fast enough" to meet expectations. From an economic development perspective, population decline or stagnation is problematic because population growth is strongly linked to gross domestic product (GDP) growth. From a community perspective, population decline can lead to loss of tax revenue, loss of services, loss of community identity, and loss of quality of life (Elshof \& Bailey, 2015; Gibson et al., 2015; Harling Stalker \& Phyne, 2014). These problems are apparent mainly in rural communities, but they also crop up in larger regions where populations are shrinking, aging, or stagnant and where economies are heavily dependent on exogenous markets. In many countries, including Australia and Canada, population decline in shrinking communities compels scholars to focus their attention on population renewal, and accordingly, on local youth, whose decisions to stay or leave will have the most impact on a shrinking community's demographics.

There was a tendency in early research on youth mobilities to reduce youth outmigration to purely economic factors — the "push" of high unemployment in the area and the "pull" of opportunities elsewhere. That narrow understanding of why people move was subsequently expanded by scholars who urged their fields to consider intersecting economic and non-economic factors (Foster \& Main, 2018; Halfacree, 2004). After the 1990s, studies that attended to young people's identities, feelings of belonging, relationships to others, and attachments to place proliferated (Annes \& Redlin, 2012; Cairns, 2014; Elder et. al, 1996; Ní Laoire, 2000). Additionally, more critical and complex articulations of economic determinants of mobility emerged, with scholars conceptualizing mobility as a social and economic resource that is not equally distributed (Evans, 2016; Norman \& Power, 2015), and observing that the predisposition to migrate may well be biographical (Ní Laoire, 2000) but is also deeply related to class and shaped by an individual's socioeconomic status (Evans, 2016; Foster \& Main, 2018).

Despite the primacy of scholarly focus attending to the economic factors of outmigration such as employment opportunities, local labour markets, and education - there is little to no research that examines the role of personal debt in an individual's decision to stay or leave their current community. This is surprising given the prevalence of debt in everyday life and growing sociological inquiry into this topic; as Adkins (2016) stated, debt is "central to understanding the lived present" (p. 319). Debt — student debt, mortgages, credit cards, etc. — is central to contemporary life. It inherently shapes future possibilities and people's understandings of their futures (see, e.g., Adkins, 2017; Davis \& Cartwright, 2019; Kirwan et al., 2019; Kotsko, 2018; Lazzarato, 2015). On this basis, we propose that debt is a missing piece of the puzzle for discussions about community outmigration, as it could affect motivations to migrate (e.g., to earn more money to repay debts as a result of declining local economies) or it could act as a barrier to mobility. 
This paper uses quantitative data from a regional survey conducted by the Rural Futures Research Centre at Dalhousie University on work and community in Atlantic Canada to assess the role of personal debt in plans to stay in or leave communities in the region (Foster et al., 2020). The data's limitations prevent us from making any grand conclusions, but our findings do support our main contention that personal debt might have some underexamined impact on youth outmigration. We begin this paper by reviewing the literature on rural outmigration, with a focus on socioeconomic factors such as labour markets, employment, and educational opportunities. We then review scholarship on the role of debt in 21 st century economies and societies, before turning to the presentation of our own survey data and analysis.

\section{Youth Outmigration from Shrinking Places}

Most of the literature on youth outmigration is about young people growing up in rural communities - the "countryside". We contend that the findings and theories that emerge from this field of study apply as well to young people growing up anywhere that population loss or stagnation is a concern. This is apparent to us as residents of Nova Scotia, in Canada's Atlantic region. Despite having a number of cities (although no major metropolitan areas), and despite some modest population growth in the past few years, the four provinces that comprise Atlantic Canada - New Brunswick, Nova Scotia, Prince Edward Island, and Newfoundland and Labrador - have been labelled Canada's "incredible shrinking region" and have, accordingly, been very concerned about population aging and loss (Ibbitson, 2015).

The scholarship on rural youth outmigration, especially that led by scholars in the United Kingdom, Ireland, Australia, and Canada, has evolved into a body of literature that resists homogenizing rural youths' experiences and identity construction (Leyshon, 2008; Looker \& Naylor, 2009), emphasizes that young people have agency (Jones, 1999), and appreciates that not only economic factors, but a number of intersecting non-economic and economic factors may influence decisions to stay in or leave one's community (Foster \& Main, 2018; Halfacree, 2004). For the purposes of brevity and focus in this paper, we concentrate on factors that might be categorized as "economic" - those that pertain to employment and education - even though these are only analytically separable from relational and subjective factors; in real life, all of these factors blur together.

Employment is a major economic factor. Job or career opportunities are recognized as major challenges facing youth in rural communities. Employment in rural and peripheral places is often characterized as being of lower quality: short-term, part-time, and casual, with lower pay (Alston \& Kent, 2009; Bednař́ková et al., 2016; Culliney, 2017; Evans, 2016; Looker \& Naylor, 2009). Importantly, in most jurisdictions there might bewith employment problems, the real issue is not the lack of jobs, but the lack of good jobs (Harling Stalker \& Phyne, 2014; Norman \& Power, 2015).

Work in rural communities is often concentrated in either service industries, which tend toward worse working conditions and remuneration, or primary industries, which can suffer from the 
stigma of "unskilled", dirty, or dangerous work that is typically gendered (Johansson, 2016; Measham \& Fleming, 2014; Rauhut \& Littke, 2016). Even if there are technically enough jobs available, and even if they pay decently and are enjoyable, they can still be stigmatized as the jobs a rural young adult falls into when they have no "better" option (Looker \& Naylor, 2009). Young people have been found to underestimate the available job opportunities in rural and peripheral places; both an actual lack of good jobs and a perceived lack of jobs have been consistently found to influence young people's propensity to leave their communities of origin (Foster \& Main, 2018).

Turning to education, there are similar challenges of access and stigma, with impacts on young adults' migration decisions., people who stay are much less likely to access post-secondary education than those who make the decision to leave home to reside in urban areas (AbbottChapman et al., 2014; Byun et al., 2012; Corbett, 2010; Geller, 2015; Hektner, 1995; Khan, 2015; Petrin et al., 2014; Punch \& Sugden, 2013; Sherman \& Sage, 2011; Theodori \& Theodori, 2015). In part, this is because there are fewer post-secondary institutions in rural communities, but that is not the whole explanation. In some cases, (e.g., for young people from lower income households) affordability is an issue, because of the high cost of post-secondary education and a lack of financial resources (Alston \& Kent, 2009). Yet, there are other factors besides access and affordability influencing the decision of whether to pursue post-secondary education.

Because getting educated is associated with outmigration, rural young peoples' aspirations toward post-secondary education are affected by place attachment, self-identity, and family relationships (San Antonio, 2016). Michael Corbett's work in Atlantic Canada has shown that compulsory schooling sorts rural students on the basis of their cultural capital, and directs those with the kind of cultural capital valued in local markets toward traditional local jobs (and thus, staying "home"), and those with cultural capital valued in urban centres toward higher education (and thus, outmigration; Corbett, 2006, 2007a, 2007b, 2009, 2010). Students who are successful in secondary school effectively "learn to leave" (Corbett, 2007b), while, for those who feel out of place in the classroom and whose knowledge and interests do not "resonate" there, opportunities outside the local community become "mute" (Rosa, 2019). Relatedly, wanting to leave has been linked to having parents who are from, or have lived in, an urban area, and to having parents with post-secondary education, suggesting that families pass on an appreciation for, and openness to, mobility, as well as the cultural and economic capital to make mobility happen (Foster \& Main, 2018; Jones, 1999).

Corbett (2007b) found that there is also a gendered dimension to the "learning to leave" phenomenon, with men much more likely to feel alienated at school and rewarded in the local, traditional milieu; this manifests as a gendered bias in mobility, evident across the youth outmigration literature. Young women are more likely to move to urban areas (Looker \& Naylor, 2009), and young women who stay in rural communities can have a more difficult time accessing educational and economic opportunities than their male counterparts (Alston \& Kent, 2009; Corbett, 2007a; Looker \& Naylor, 2009). 
International Journal of Child, Youth and Family Studies (2021) 12(2): 25-47

Both Corbett (2007a) and Norman and Power (2015) found that for young women living in Atlantic Canada, upward mobility was associated with outward mobility, especially in terms of formal education. In a more recent study, Power and Norman (2019) examine how gender relations in rural areas inform possible mobilities, particularly in the context of resource extraction industries. Embedded practices over the life course result in conventions of men working outdoors with their hands, and in contrast, women working indoors, often in positions where they provide care and services to others. Gendered structures of labour, opportunity, and social relations intersect with forms of discrimination and patterns of inequality, such as those associated with race and sexuality (Annes \& Redlin, 2012; Cairns, 2013), but we must limit our discussion of these factors as our data do not permit any further analysis along these lines. For our purposes, the takeaway from the foregoing discussion is that young people, and especially women, leave their home communities in pursuit of, and then because of, higher education. Moreover, income can be expected to impact migration: people from extremely low income households might be compelled to migrate to earn more money, while those who have very high incomes are expected and able to move in pursuit of opportunities. We do not dispute these well-established points, but we do wish to illuminate one factor in household and individual resources that does not get much attention in youth outmigration research: personal debt.

\section{Personal Debt}

Debt is central to everyday lived experience in the current phase of capitalism, which is often characterized by scholars as "neoliberal" (Bowsher, 2018; Chakravatty \& Ferreira da Silva, 2012; Lazzarato, 2012, 2015; Soderberg, 2014). In A Brief History of Neoliberalism, Harvey (2007) regarded this era as having begun approximately four decades ago, in the late 1970s to early 1980s. Although fleshing out the term neoliberalism - which is notably contested and complex - is beyond the scope of this paper, it is sufficient to explain that neoliberalism is both a theory and a practice (which Harvey refers to as "neoliberalization"), in which a market rationale is imposed onto both the state and the social world (Brown, 2006; Harvey, 2007). Market terms come to decipher and define non-market relations as the terms find application beyond the economic and into the social, political, educational, and cultural realms of society (Brown, 2011; Foucault, 2008).

Scholars have noted the importance of debt as a mechanism for capitalist accumulation in the neoliberal era. Debt servicing - the interest and principal amounts paid on debts by wage earners - facilitates the precaritization and flexibilization of labour (Barba \& Pivetti, 2009) and the capture and redistribution of wealth from the poor to the rich, while making it possible for capital to cross space and time in unprecedented ways (Barba \& Pivetti, 2009; Federici, 2014; Kotsko, 2018; Lazzarato, 2012, 2015; Williams, 2004).

At both the macro and micro levels, the "intensification" of debt over time - more people have it, and more of it - results in what Kotsko (2018) referred to as "temporal colonization":

In a world where there is increasingly no outside to colonize, no significant territory that has yet to be incorporated into the capitalist order, we can view the explosion 
International Journal of Child, Youth and Family Studies (2021) 12(2): 25-47

of debt as a form of temporal colonization, using the future itself as a site of primitive accumulation. This temporal colonization, like its geographical development, serves a productive purpose in the capitalist system; so too can variations in life chances be converted into varying levels of "risk" to be incorporated into complex financial strategies - in subprime loans, for instance, which actually prove more profitable, not despite but because of the fact that they are less likely to be paid off. (p. 122)

In the context of stagnating and falling wages, and the defunding and privatization of the welfare state and social services in many "advanced" nations, debt also serves the function of maintaining consumption levels crucial to the continuance of capitalism (Barba \& Pivetti, 2009; LeBaron \& Roberts, 2012). People can continue to buy more goods even when their incomes are falling short.

There has been growing sociological inquiry on debt since the 2008 financial crisis, and a growing body of scholarship has emerged. Debt, according to Lazzarato (2015), captures not just both wealth and future profitability, but also "possibility" (p. 23); it reorganizes the experience of time and people's views of the future (Adkins, 2017). This especially impacts young people, who are often viewed as standing at the threshold of their adult lives with numerous possible futures before them. Davis and Cartwright's (2019) qualitative study of young and precarious workers found that indebtedness inhibited progress in life narratives and delayed important biographical goals and life milestones. Similarly, in another qualitative study, Kriwan et al. (2019) found that the quantitative expansion of debt levels was less important to research participants than the inability of the indebted to imagine a stable future where they had the ability to repay their debts.

Debt is increasingly normalized; this is obvious when one considers the ubiquity of student debt. In Canada, in the year ending July 31, 2017, over a million and a half people carried student debt (Employment and Social Development Canada, 2019). Nowadays, it is usually only by entering into creditor-debtor relations that individuals can afford major items that are perceived as essential (houses, cars, education), or can access the credit needed for building wealth (Dwyer, 2018). However, the experience of debt varies across social locations. Various laws and policies, in conjunction with some conditions of accessing credit, have either excluded certain populations from participating in credit markets altogether on the basis of gender, race, or class position (e.g., "redlining" or subprime lending), or have required them to participate on unequal terms (Chakravartty \& Ferreira da Silva, 2012; Dwyer, 2018; Dymski, 2009).

The literature on debt also presents a hierarchization and classification into "good" and "bad" debts. Participants in Davis and Cartwright's (2019) study associated good debts with the purchase of an appreciating or secure asset (e.g., a mortgage). In contrast, bad debts were often associated with unsecured forms of lending used for the purchase of consumer goods or depreciating assets (e.g., credit card debt). Participants also related different kinds of debts to socially and culturally appropriate norms over the life course. The "good" types of debt (e.g., student loans) were 
International Journal of Child, Youth and Family Studies (2021) 12(2): 25-47

recognized as providing opportunities for social mobility, while the "bad" debts may prevent this type of mobility or delay appropriate steps in the life course (Davis \& Cartwright, 2019).

Summarizing the complex relationship between credit and debt, Dwyer (2018) wrote: "Even at their best, credit and debt entail tensions between investment and risk, resource and liability, security and insecurity, freedom and trap, democracy and dependency" (p. 240). Despite scholarly focus on economic factors in decision-making around youth outmigration, and the growing sociological inquiry into personal debt and its role in our everyday lives, there is little to no research into the intersections of these two fields of study. Our research begins to fill this gap in the literature.

\section{Atlantic Canada as a Case Study}

We selected Atlantic Canada as a case study for this exploratory study of debt and outmigration. The region provides a suitable and interesting context for this inquiry as it is characterized by some of the lowest wages, highest unemployment rates, highest tuition fees, and persistent youth outmigration in Canada; it also offers an abundance of work that is both precarious and seasonal (Conference Board of Canada, 2018; Foster, 2018; Saulnier, 2018, 2019). The region has seen some population growth in recent years, especially in Nova Scotia's capital city of Halifax, but looking over the past decade, the region lags behind the rest of the country; the enduring view of its four provinces - an unfair one, perhaps — is that they are economic laggards (Conference Board of Canada, 2017). These circumstances, coupled with debt accumulation, could have implications on choices to outmigrate from the region, yet analysis that connects these dots is rare in the literature on migration and mobility (see Foster \& Main, 2018). In the Atlantic region, the last comprehensive report on personal debt in its four provinces was released over a decade ago, in 2008. Using Statistics Canada data, Tran and Colman (2008) found that Atlantic Canadian households were accumulating debt at a rate faster than the national average, and that a greater proportion of households in the region were in debt compared to other Canadian regions. Therefore, debt could be an important, underexamined factor shaping the lives and livelihoods of Atlantic Canadians.

\section{Methods}

The data analyzed here were collected in a telephone survey conducted by the Rural Futures Research Centre at Dalhousie University on community, work, and income in Atlantic Canada (Foster et al., 2020). The survey was conducted in 2019 and included a total of 1,277 respondents from the four Atlantic Canadian provinces: Prince Edward Island, Nova Scotia, New Brunswick, and Newfoundland and Labrador. Respondents were located in urban, suburban, and rural communities and were recruited through a random selection of landline and cellphone numbers assigned to the sampled region. Those aged 16 or over who resided in one of the four selected provinces were eligible for participation. 
Comparing descriptive statistics from the sample to the 2016 census profiles of each Atlantic Canadian province (Statistics Canada, 2016; see Tables 4 and 5 in Appendix), we find that women participants are overrepresented in our sample by approximately $8 \%$, and men underrepresented by approximately $8 \%$. The sample is underrepresentative of Atlantic Canadians who are employed by approximately $9 \%$, but closely reflects the average unemployment rate of the region. While our sampling frame was different from the census (in that we exclude anyone under 16), a rough comparison shows that younger people are underrepresented in our sample, and older people are overrepresented. The middle-age categories of " $40-49$ " and "50-59" in the sample most accurately reflect the Atlantic Canadian region.

Although our objective is to contribute to the youth outmigration literature, we include older adults in our analysis for two reasons: the first is that only studying the youth in our sample would yield too small a sample for much further analysis. The Atlantic Provinces have the oldest populations in Canada (Statistics Canada, 2020), and our full sample reflects that. The second, and the rationale for proceeding with this sample at all, is that it is important to establish whether or not young people have a distinctly "young" relationship to debt compared to older people. Including all ages in the analyses means we can control for age and determine its influence on results within the sample.

The outcome variable in our analysis is propensity to leave, a binary variable (yes = likely to leave; no = not likely to leave) created by combining the results of two questions asked of participants related to leaving their current communities. The first question was, "Do you think you will ever move away from your current community?" with options of yes, no, or maybe. The second question asked their level of agreement, on a 5-point scale from strongly disagree to strongly agree, with the statement: "I often think seriously about moving away to earn more money." In the resulting propensity to leave variable, the "yes" category includes the responses from (a) those who answered "yes" and "maybe" when asked if they thought they would move from their current community, and (b) those who answered "strongly agree" or "agree" to the statement that they often thought seriously about moving away to earn more money. The "no" category includes (a) those who responded "no" to planning to move from their current community, and (b) those who answered "strongly disagree" or "disagree" to the statement that they often thought seriously about moving away to earn more money. Neutral responses on the 5point scale were excluded from the analysis $(n=86)$.

We used three explanatory variables in our analysis. The first measures personal debt. The survey asked all participants whether they had any personal debt that they were partially or fully responsible for paying off (yes or no). The second explanatory variable measures types of debt by asking participants to indicate which of six different kinds of debt (mortgage, student loan, credit card, bank line of credit, payday loan, and car payment) they carry. The third explanatory variable measures participants' comfort with debt levels. Participants were asked to indicate their level of agreement with the statement, "I am comfortable with the amount of debt I currently carry", again 
on a 5-point scale. The responses were then collapsed into three main categories for analysis: strongly agree/agree, neutral, and strongly disagree/disagree.

Informed by both the outmigration and debt literature, we controlled for participant socioeconomic status. We measured this with three variables: employment status, income level, and education level. For employment status, participants indicated whether or not they were currently employed (yes or no). If they indicated they were unemployed, they were asked a second prompt question, listing options that best reflected their current situation. Those who indicated they were fully retired, or retired from a career but still working part-time, were categorized as "retired", and all others were categorized as "unemployed". Income level was measured by participant's reported household income, and this variable was then coded into seven income groups from the lowest group of " $\$ 20,000$ or less" to the highest, " $\$ 150,000$ or more". Education level measures the highest level of education obtained by the participant. This variable was then coded into four main categories: less than high school, high school, college/trade, and university.

Age, as previously mentioned, was measured in order to compare young people to older people. The age variable, from a question that asked respondents to report their age, has been recoded into four categories (29 and younger, 30-49, 50-69, 70 and older). Given the demonstrated importance of gender in the literature on community outmigration and personal debt, we also controlled for gender. Although we did not delve into the literature on race and ethnicity, we also included two binary variables meant to capture these characteristics (visible minority and Indigenous). The community variable was used to account for participants' self-reported community type (urban, rural, suburban).

We used cross-tabular analysis and binary logistic regression as methods of our inquiry. The analyses were conducted using the statistical software, Stata. We began with a basic cross-tabular analysis showing the individual relationships between the explanatory and control variables and the outcome, propensity to leave (see Table 1).

Next, we prepared two tables of logistic regression models. Table 2 presents the odds ratio results for participants carrying personal debt and their propensity to leave their communities, while accounting for measures of socioeconomic status, sociodemographic characteristics, and community type. To avoid collinearity of variables in the analysis, the explanatory variable personal debt is presented in a separate model from the other explanatory variables that examine the characteristics of personal debt. The second logistic regression table, Table 3, presents the types of debt participants indicated they were carrying, along with the indicated comfort level with current debt amounts and the effect on their propensity to leave, while also controlling for all other measures. 
International Journal of Child, Youth and Family Studies (2021) 12(2): 25-47

\section{Results}

First, we examine basic cross-tabular relationships between the independent variables and the propensity to leave variable (see Table 1).

Table 1. Cross-Tabular Relationships: Explanatory Variables and Propensity to Leave

\begin{tabular}{|c|c|c|c|}
\hline Explanatory variable & $\begin{array}{c}\text { Propensity to leave: } \\
\text { Yes }(\%)\end{array}$ & Explanatory variable & $\begin{array}{c}\text { Propensity to leave: } \\
\text { Yes }(\%)\end{array}$ \\
\hline Personal debt & & Education & \\
\hline No & $31.25^{* *}$ & Less than high school & $15.73^{* *}$ \\
\hline Yes & $43.94 * *$ & High school & $38.14^{* *}$ \\
\hline Type of debt & & College/Trade & $42.86^{* *}$ \\
\hline Mortgage & $44.50^{* *}$ & University & $54.63 * *$ \\
\hline Student loans & $68.97^{* *}$ & Sociodemographic traits & \\
\hline Credit card & 42.95 & Age & \\
\hline Line of credit/Bank loan & $44.33^{*}$ & 29 and younger & $84.62^{* *}$ \\
\hline Payday loan & 64.71 & $30-49$ & $56.39^{* *}$ \\
\hline Car payment & 57.01 & $40-69$ & $36.95^{* *}$ \\
\hline Comfort with debt & & 70 and older & $20.89 * *$ \\
\hline Strongly & & Gender & \\
\hline disagree/Disagree & $52.40 * *$ & Male & $44.64 *$ \\
\hline Neutral & $46.95^{* *}$ & Female & $36.79 *$ \\
\hline Strongly agree/Agree & $34.26^{* *}$ & Visible minority & \\
\hline Socioeconomic status & & No & 39.61 \\
\hline Employment status & & Yes & 43.02 \\
\hline Employed & $51.21^{* *}$ & Indigenous & \\
\hline Unemployed & $49.62 * *$ & No & 38.16 \\
\hline Retired & $26.06^{* *}$ & Yes & 40.00 \\
\hline Income & & Community type & \\
\hline$\$ 20,000$ or less & $43.69^{*}$ & Urban & 40.84 \\
\hline$\$ 21,000-\$ 40,00$ & $30.00^{*}$ & Rural & 38.39 \\
\hline$\$ 41,000-\$ 60,000$ & $34.65^{*}$ & Suburban & 40.09 \\
\hline$\$ 61,000-\$ 80,000$ & $44.12^{*}$ & & \\
\hline$\$ 81,000-\$ 100,000$ & $46.85^{*}$ & & \\
\hline$\$ 101,000-\$ 150,000$ & $46.99 *$ & & \\
\hline Over $\$ 150,000$ & $48.91 *$ & & \\
\hline
\end{tabular}

$* \mathrm{p}<.05, * \mathrm{*} p<.001$

The data show that a higher proportion of those with personal debt have a propensity to leave their current community: $43.9 \%$ of participants who carried some form of personal debt had a propensity to leave, compared to $31.2 \%$ who reported having no debt. Looking at the type of debt a participant carried and their propensity to leave, a higher proportion of participants carrying student debt reported having a propensity to leave their communities $(68.9 \%)$, followed by those who carried payday loans (64.7\%). There is also a bivariate relationship between participants' debt 
comfort levels and propensity to leave. A higher proportion of participants who said they were not comfortable with their current debt level had a propensity to leave $(52.4 \%)$ in comparison to those who said they were comfortable with their current debt amounts (34.3\%).Almost equal proportions of respondents who were employed $(51.2 \%)$ and unemployed $(49.6 \%)$ reported having a propensity to leave, compared to those who were retired (26\%). We next examine participants' income levels and the relationship with propensity to leave. Bivariate results here support the findings of previous outmigration studies: people with very low incomes (under \$20,000/year) and people with higher incomes $(\$ 61,000$ and over) were more likely to anticipate leaving than people with incomes in the middle $(\$ 21,000-\$ 60,000)$. There is also a clear pattern involving participant education level and propensity to leave: as education level increases so does the proportion of participants who have a propensity to leave (e.g., 15.7\% in the "less than high school" category, compared to $54.6 \%$ in the "university" category). In contrast to the education level pattern, as age increases, the proportion of participants with a propensity to leave decreases. For example, $84.6 \%$ in the age category "29 and under" had a propensity to leave compared to only $20.8 \%$ in the "70 and older" age category.

When we examine gender, we see that a higher proportion of men $(44.6 \%)$ had a propensity to leave than women (36.7\%). Both visible minorities (43\%) and Indigenous peoples (40\%) reported a propensity to leave in slightly higher proportions than non-visible minorities $(39.6 \%)$ and nonIndigenous people (38.1\%). Similarly, looking at the relationship between community type and propensity to leave, there is surprisingly little variation between participant community types and proportion of participants with a propensity to leave (40.8\% for urban, $38.3 \%$ for rural, and $40 \%$ for suburban). This suggests that our decision to include all community types is warranted, as the cities in Atlantic Canada, which are small by Canadian standards, face problems of outmigration similar to their rural counterparts. When we consider statistical significance for the population, while our sample is not representative, we can see that most relationships in Table 2 are statistically significant with the exception of certain variable relationships involving debt types, visible minority, Indigenous, and community type.

To further examine whether debt affects odds of having a propensity to leave, we present two logistic regression models which account for the various explanatory variables measuring debt, while also controlling for other factors identified in the literature that may affect the odds of having a propensity to leave. Table 2 looks at whether having personal debt affects the odds of having a propensity to leave while accounting for participant socioeconomic status, sociodemographic characteristics, and community type. From this model we see that participants with personal debt are $28 \%$ more likely to have a propensity to leave their current communities than someone without any personal debt; however, this is not statistically significant for the population. Those who are employed have increased odds of approximately $30 \%$ to have a propensity to leave compared to retirees, while those who are unemployed have increased odds of $13 \%$ compared to retirees. Controlling for other variables, all income levels have decreased odds of having a propensity to leave compared to the reference category of " $\$ 20,000$ or less". For example, those in the income 
category of " $\$ 101,000-\$ 150,000 "$ have decreased odds of approximately $50 \%$ compared to the lowest income category. Looking at the education variable, an increase in education level is associated with higher odds of having a propensity to leave; for example, those with a university education are almost four times as likely $(O R=3.834)$ to have a propensity to leave than those in the reference category of "less than high school". On the other hand, a categorical increase in age decreases the odds of having a propensity to leave. Participants in the youngest age category of "29 and younger" are approximately 20 times more likely to have a propensity to leave compared to the oldest age category of "70 and older".

Table 2. Logistic Regression: Personal Debt and Propensity to Leave

\begin{tabular}{|c|c|c|c|c|c|}
\hline \multirow[b]{2}{*}{ Y: Propensity to move } & \multicolumn{2}{|c|}{ Model } & \multirow[b]{2}{*}{ Y: Propensity to move } & \multicolumn{2}{|c|}{ Model } \\
\hline & Odds ratio & $p$ & & Odds ratio & $p$ \\
\hline Personal debt & & & Sociodemographic traits & & \\
\hline No & ref. & & Age & & \\
\hline Yes & 1.280 & .100 & 29 and younger & 19.963 & $<.001$ \\
\hline Socioeconomic status & & & $30-49$ & 3.566 & $<.001$ \\
\hline Employment status & & & $40-69$ & 1.942 & .001 \\
\hline Employed & 1.307 & .128 & 70 and older & ref. & \\
\hline Unemployed & 1.132 & .637 & Gender & & \\
\hline Retired & ref. & & Male & ref. & \\
\hline Income & & & Female & 0.915 & .510 \\
\hline$\$ 20,000$ or less & ref. & & Visible minority & & \\
\hline$\$ 21,000-\$ 40,00$ & 0.520 & .023 & No & ref. & \\
\hline$\$ 41,000-\$ 60,000$ & 0.522 & .025 & Yes & 1.139 & .622 \\
\hline$\$ 61,000-\$ 80,000$ & 0.692 & .227 & Indigenous & & \\
\hline$\$ 81,000-\$ 100,000$ & 0.682 & .216 & No & ref. & \\
\hline$\$ 101,000-\$ 150,000$ & 0.497 & .025 & Yes & 0.812 & .475 \\
\hline Over $\$ 150,000$ & 0.564 & .096 & Community type & & \\
\hline Education & & & Urban & ref. & \\
\hline Less than high & & & Rural & 0.948 & .715 \\
\hline school & ref. & & Suburban & 0.811 & .307 \\
\hline High school & 2.745 & .004 & & & \\
\hline College/Trade & 3.135 & .001 & & & \\
\hline University & 3.834 & $<.001$ & & & \\
\hline
\end{tabular}

Note. $n=1,178 . n$ is smaller than the total sample of 1,277 as certain variable responses (e.g., "don't know/refused") were coded as missing when doing the regression analysis. ref. $=$ reference category.

Gender has little effect on the odds of having a propensity to leave: women have a decrease in odds of only about $8.5 \%$ compared to men. Identifying as a visible minority increases the odds of having a propensity to leave by approximately $14 \%$ compared to non-visible minorities, while identifying as Indigenous decreases the odds of having a propensity to move by approximately $19 \%$ compared to non-Indigenous people. Finally, residing in rural and suburban communities 
decreases the odds of having a propensity to move compared to those residing in urban areas in Atlantic Canada, by approximately 5\% for rural residents and 19\% for suburban residents.

In Table 3, we examine how the characteristics of debt, and comfort with carrying debt, affect the odds of having a propensity to leave one's current community, while controlling for socioeconomic status, sociodemographic characteristics, and community type.

Table 3. Logistic Regression: Characteristics of Debt and Propensity to Leave Community

\begin{tabular}{|c|c|c|c|c|c|}
\hline \multirow[b]{2}{*}{ Y: Propensity to leave } & \multicolumn{2}{|c|}{ Model } & \multirow[b]{2}{*}{ Y: Propensity to leave } & \multicolumn{2}{|c|}{ Model } \\
\hline & Odds ratio & $p$ & & Odds ratio & $p$ \\
\hline Type of debt & & & Education & & \\
\hline Mortgage & 1.284 & .018 & Less than high school & ref. & \\
\hline Student loan & 1.179 & .545 & High school & 2.484 & .011 \\
\hline Credit card & 0.702 & .032 & College/Trade & 2.859 & .003 \\
\hline Line of credit/Bank loan & 0.915 & .577 & University & 3.441 & .001 \\
\hline Payday loan & 1.499 & .233 & Sociodemographic traits & & \\
\hline Car payment & 0.879 & .419 & Age & & \\
\hline Comfortable with debt & & & 29 and younger & 17.556 & $<.001$ \\
\hline Strongly disagree/Disagree & 1.703 & .003 & $30-49$ & 3.933 & $<.001$ \\
\hline Neutral & 1.367 & .113 & $40-69$ & 2.054 & $<.001$ \\
\hline Strongly agree/Agree & ref. & & 70 and older & ref. & \\
\hline Socioeconomic status & & & Gender & & \\
\hline Employment status & & & Male & ref. & \\
\hline Employed & 1.261 & .194 & Female & 0.906 & .474 \\
\hline Unemployed & 0.977 & .934 & Visible minority & & \\
\hline Retired & ref. & & No & ref. & \\
\hline Income & & & Yes & 1.037 & .893 \\
\hline$\$ 20,000$ or less & ref. & & Indigenous & & \\
\hline$\$ 21,000-\$ 40,00$ & 0.502 & .022 & No & ref. & \\
\hline$\$ 41,000-\$ 60,000$ & 0.551 & .048 & Yes & 0.800 & .452 \\
\hline$\$ 61,000-\$ 80,000$ & 0.715 & .288 & Community type & & \\
\hline$\$ 81,000-\$ 100,000$ & 0.693 & .257 & Urban & ref. & \\
\hline$\$ 101,000-\$ 150,000$ & 0.550 & .067 & Rural & 0.952 & .741 \\
\hline Over $\$ 150,000$ & 0.629 & .199 & Suburban & 0.828 & .369 \\
\hline
\end{tabular}

Note. $n=1,144 . n$ is smaller than the total sample of 1,277 as some observations in variables (e.g., "don't know/refused") were coded as missing when doing the regression analysis. ref. $=$ reference category.

From this model we see that there are increased odds of having a propensity to leave associated with mortgage debt (odds increase of 28\%), student loans (odds increase of 17\%), and payday loans (odds increase of 49\%). The level of comfort a participant had with their current debt affected the odds of having a propensity to leave their current community. Those who disagreed or strongly disagreed that they were comfortable with the amount of debt they currently carried had increased 
odds of $70 \%$ of having a propensity to leave their current community compared to those who agreed they were comfortable with their debt.

Similar to the results presented in Table 2, those who are employed have increased odds of having a propensity to leave by $26 \%$ compared to retirees. All income levels show decreased odds of having a propensity to leave compared to the lowest income level of " $\$ 20,000$ or less". The models presented in Tables 1 and 2 show similar trends in both the education level and age variables. As education level increases so do the odds of having a propensity to leave. Those with a university education are again almost four times as likely to have a propensity to leave than are those with less than a high school education. Participants in the younger age categories have increased odds of having a propensity to leave their current communities — approximately 17.5 times greater for participants " 29 and under" than for participants "70 and older".

In the second model, gender has a smaller effect than education level and age on participants' propensity to leave their current communities. The odds for women are decreased by approximately $10 \%$ compared to men. Similarly, the odds of visible minorities having a propensity to leave are only $3 \%$ greater than the odds for others, while Indigenous people have decreased odds of $20 \%$ of having a propensity to leave compared to non-Indigenous people. Finally, the effect of community type on having a propensity to leave is similar to that in the previous model. Those who reside in rural and suburban communities have decreased odds of having a propensity to leave compared to urban residents — decreased by approximately $5 \%$ for rural residents, and $17 \%$ for suburban residents.

Overall, our analysis demonstrates that there is a relationship between carrying debt and having a propensity to leave your community in Atlantic Canada. For the participants in the sample, carrying personal debt increased the odds of having a propensity to leave their current communities, but this relationship is not statistically significant for the population when controlling for other variables. The type of debt carried by participants affected the odds of having a propensity to leave their community. For example, there are higher odds associated with mortgage debt and this is statistically significant for the population. Our analysis also shows that comfort with personal debt may be more important than actually carrying debt. Those who reported they were not comfortable with their debt had higher odds of having a propensity to leave than those who reported they were comfortable, and this too is statistically significant.

Two control variables showed an important effect on the outcome variable across both models: education level and age. This finding aligns with the general literature on social mobility and outmigration discussed earlier. Having a higher education level and being in a younger age category increased the odds of having a propensity to leave. Income, gender, visible minority status, and Indigenous status had a smaller effect on the propensity to leave. Interestingly, we found little variation between community type and the odds of having a propensity to leave, especially between urban and rural communities. Although age is statistically accounted for and controlled for in the models, this might be explained by the fact that rural residents are more likely 
to be older. It might also stem from the fact that the Atlantic provinces (which, as explained earlier, are perceived as being peripheral to the Canadian economy) have only small urban centres compared to metropolises such as Montreal, Vancouver, and Toronto, and so perhaps contrast less with rural areas than do those larger cities in other provinces. This finding challenges the ruralurban binary in studies of rural outmigration and is worth investigating further.

\section{Conclusion}

This research sought to understand whether personal debt can be considered as a factor in decisions to outmigrate. Using Atlantic Canada - a region with persistent outmigration - as a case study, we found that carrying debt, having certain types of debt, and comfort levels with debt affect the odds of having a propensity to leave the current community. Despite some workers in the field beginning to acknowledge more complex and subjective aspects of migration (Foster \& Main, 2018), economic factors remain prevalent in the literature on outmigration. It is important to consider personal debt as an additional economic factor in outmigration. This is especially true given debt's ubiquity in the lived realities of 21 st century capitalism. This research has therefore laid the groundwork for future scholarship in this area, demonstrating that there is a relationship between personal debt and propensity to leave. Future research, using a sample that includes more youth, and including data on intended destination (e.g., urban or rural), or focusing on actual movements rather than intentions, could shed more light on the relationship between personal debt and young people's migration from places that are losing their population. 
International Journal of Child, Youth and Family Studies (2021) 12(2): 25-47

\section{References}

Abbott-Chapman, J., Johnston, R., \& Jetson, T. (2014). Rural belonging, place attachment and youth educational mobility: Rural parents' views. Rural Society, 23(3), 296-310. https://doi.org/10.1080/10371656.2014.11082072

Adkins, L. (2016). Notes toward a sociology of debt. Dialogues in Human Geography 6(3), 318321. doi:10.1177/2043820616676728

Adkins, L. (2017). Speculative futures in the time of debt. The Sociological Review 65(3), 448462. doi:10.1111/1467-954X.12442

Alston, M., \& Kent, J. (2009). Generation X-pendable: The social exclusion of rural and remote young people. Journal of Sociology 45(1), 89-107. doi:10.1177/1440783308099988

Annes, A., \& Redlin, M. (2012). Coming out and coming back: Rural gay migration and the city. Journal of Rural Studies, 28(1), 56-68. doi:10.1016/i.jrurstud.2011.08.005

Barba, A., \& Pivetti, M. (2009). Rising household debt: Its causes and macroeconomic implications — a long-period analysis. Cambridge Journal of Economics 33, 113-137. $\underline{\text { doi: } 10.1093 / \text { cje/ben030 }}$

Bednaříková, Z., Bavorová, M., \& Ponkina, E. V. (2016). Migration motivation of agriculturally educated rural youth: The case of Russian Siberia. Journal of Rural Studies 45, 99-111. doi:10.1016/j.jrurstud.2016.03.006

Bowsher, J. (2018). Credit/debt and human capital: Financialized neoliberalism and the production of subjectivity. European Journal of Social Theory, 22(4), 1-20. doi:10.1177/1368431018800506

Brown, W. (2006). American nightmare: Neoliberalism, neoconservatism, and dedemocratization. Political Theory 34(6), 690-714. doi:10.1177/0090591706293016

Brown, W. (2011). Neoliberalized knowledge. History of the Present 1(1), 113-129. doi:10.5406/historypresent.1.1.0113

Byun, S., Meece, J. L., Irvin, M. J., \& Hutchins, B. C. (2012). The role of social capital in educational aspirations of rural youth. Rural Sociology, 77(3), 355-379. doi:10.1111/j.1549$\underline{0831.2012 .00086 . x}$

Cairns, K. (2013). Youth, dirt, and the spatialization of subjectivity: An intersectional approach to White rural imaginaries. Canadian Journal of Sociology 38(4), 623-646.

$\underline{\text { doi: } 10.29173 / \operatorname{cjs} 21199}$ 
International Journal of Child, Youth and Family Studies (2021) 12(2): 25-47

Cairns, K. (2014). Both here and elsewhere: Rural girls' contradictory visions of the future. Gender and Education, 26(5), 477-489. doi:10.1080/09540253.2014.927835

Chakravartty, P., \& Ferreira da Silva, D. (2012). Accumulation, dispossession, and debt: The racial logic of global capitalism — An introduction. American Quarterly 64(3), 361-385. doi:10.1353/aq.2012.0033

Conference Board of Canada. (2017). Provincial and territorial ranking: Economy. https://www.conferenceboard.ca/hcp/provincial/economy.aspx

Conference Board of Canada. (2018). How Canada performs: Economy. https://www.conferenceboard.ca/hcp/provincial/economy.aspx

Corbett, M. (2006). Educating the country out of the child and educating the child out of the country: An excursion in spectrology. Alberta Journal of Educational Research, 52(4), 289301.

Corbett, M. (2007a). All kinds of potential: Women and out-migration in an Atlantic Canadian coastal community. Journal of Rural Studies, 23(4), 430-442.

doi:10.1016/j.jrurstud.2006.12.001

Corbett, M. (2007b). Learning to leave: The irony of schooling in a coastal community. Fernwood.

Corbett, M. (2009). Rural schooling in mobile modernity: Returning to the places I've been. Journal of Research in Rural Education, 24(7), 1-13.

Corbett, M. (2010). Standardized individuality: Cosmopolitanism and educational decisionmaking in an Atlantic Canadian rural community. Compare: A Journal of Comparative and International Education, 40(2), 223-237. doi:10.1080/03057920903546088

Culliney, M. (2017). Escaping the rural pay penalty: Location, migration and the labour market. Work, Employment and Society 31(3), 429-446. doi:10.1177/0950017016640685

Davis, M., \& Cartwright, L. (2019). 'Deferred lives': Money, debt and the financialised futures of young temporary workers. In M. Featherstone (Ed.), The Sociology of Debt (pp. 92-18). Policy Press. doi:10.1332/policypress/9781447339526.003.0005

Dwyer, R. E. (2018). Credit, debt, and inequality. Annual Review of Sociology 44, 237-261. doi:10.1146/annurev-soc-060116-053420

Dymski, G. (2009). Racial exclusion and the political economy of the subprime crisis. Historical Materialism 17(2), 149-179. doi:10.1163/156920609X436162 
International Journal of Child, Youth and Family Studies (2021) 12(2): 25-47

Elder, G. H., King, V., \& Conger, R. D. (1996). Attachment to place and migration prospects: A developmental perspective. Journal of Research on Adolescence, 6(4), 397-425.

Elshof, H., \& Bailey, A. (2015). The role of responses to experiences of rural population decline in the social capital of families. Journal of Rural and Community Development, 10(1), 72-93.

Employment and Social Development Canada. (2019). Canada Student Loans Program

statistical review 2016 to 2017. https://www.canada.ca/en/employment-social-

development/programs/canada-student-loans-grants/reports/cslp-statistical-2016-

2017.html\#h2.3.

Evans, C. (2016). Moving away or staying local: The role of locality in young people's 'spatial horizons' and career aspirations. Journal of Youth Studies, 19(4), 501-516. doi:10.1080/13676261.2015.1083955

Federici, S. (2014). From commoning to debt: Financialization, microcredit, and the changing architecture of capital accumulation. Southern Atlantic Quarterly, 113(2), 231-244. $\underline{\text { doi:10.1215/00382876-2643585 }}$

Foster, K., Gerhardt, A., \& Main, H. (2020). Seeing a future in it: 2019 survey report [Report]. Rural Future Research Centre. https://rfrc.ca/sites/default/files/2020-09/IG\%20\%20Seeing $\% 20 a \% 20$ Future $\% 20-\% 20$ Survey $\% 20$ Report_FINAL.pdf.

Foster, K. (2018). Bridging import replacement theory and practice: A sociological examination of the potential for import replacement in Atlantic Canada [Report]. Centre for Local Prosperity. https://centreforlocalprosperity.ca/wp-content/uploads/2018/02/Karen-Foster-IRCase-Study-Report-Jan18.pdf

Foster, K., \& Main, H. (2018). Finding a place in the world: Understanding youth outmigration from shrinking rural communities [Social Sciences and Humanities Research Council knowledge synthesis report]. Dalhousie University. https://dalspace.library.dal.ca/bitstream/handle/10222/73932/Finding\%20a\%20Place\%20v1.p $\underline{\text { df? }}$ sequence $=1 \&$ isAllowed $=y$

Foucault, M. (2008). The birth of biopolitics. Palgrave Macmillan.

Geller, W. (2015). Rural young women, education, and socio-spatial mobility: Landscapes of success. Lexington Books.

Gibson, R., Fitzgibbons, J., \& Nunez, N. R. (2015). The state of rural Canada: Nova Scotia. Canadian Rural Revitalization Foundation. http://sorc.crrf.ca/ns/

Halfacree, K. (2004). A utopian imagination in migration's terra incognita? Acknowledging the non-economic worlds of migration decision-making. Population, Space and Place 10(3), 239253. doi:10.1002/psp.326 
International Journal of Child, Youth and Family Studies (2021) 12(2): 25-47

Harling Stalker, L., \& Phyne, J. (2014). The social impact of out-migration: A case study from rural and small town Nova Scotia, Canada. Journal of Rural and Community Development 9(3), 203-226.

Harvey, D. (2007). A brief history of neoliberalism. Oxford University Press.

Hektner, J. (1995). When moving up implies moving out: Rural adolescent conflict in the transition to adulthood. Journal of Research in Rural Education, 11(1), 3-14.

Ibbitson, J. (2015, March 20). How the Maritimes became Canada's incredible shrinking region. The Globe and Mail. http://www.theglobeandmail.com/news/national/how-the-maritimesbecame-canadas-incredible-shrinking-region/article23554298/

Johannson, M. (2016). Young women and rural exodus - Swedish experiences. Journal of Rural Studies 43, 291-300. doi:10.1016/j.jrurstud.2015.04.002

Jones, G. (1999). "The same people in the same places"? Socio-spatial identities and migration in youth. Sociology, 33(1), 1-22. doi:10.1177/S0038038599000012

Khan, F. I. (2015). Overeducation as a determinant of migrating out of a province. [Honours thesis, Saint Mary’s University]. http://library2.smu.ca/handle/01/26290\#.XsVDEBNKhp9

Kirwan, S., Dawney, L., \& Walker, R. (2019). 'Choose your moments': Discipline and speculation in the indebted every day. In M. Featherstone (Ed.), The Sociology of Debt (pp. 119-144). Policy Press. doi:10.1332/policypress/9781447339526.003.0006

Kotsko, A. (2018). Neoliberalism's demons: On the political theology of late capital. Stanford University Press.

Lazzarato, M. (2012). The making of the indebted man: An essay on the neoliberal condition. Semiotext(e).

Lazzarato, M. (2015). Governing by debt. Semiotext(e).

LeBaron, G., \& Roberts, A. (2012). Confining social insecurity: Neoliberalism and the rise of the 21 st century debtors' prison. Politics \& Gender, 8(1), 25-49.

doi:10.1017/S1743923X12000062

Leyshon, M. (2008). The betweenness of being a rural youth: inclusive and exclusive lifestyles. Social and Cultural Geography, 9(1), 1-26. doi:10.1080/14649360701789535

Looker, D., \& Naylor, T. D. (2009). "At risk" of being rural? The experience of rural youth in a risk society. Journal of Rural and Community Development, 4(2), 39-64. 
International Journal of Child, Youth and Family Studies (2021) 12(2): 25-47

Measham, T. G., \& Fleming, D. A. (2014). Impacts of unconventional gas development on rural community decline. Journal of Rural Studies, 36, 376-385.

doi:10.1016/j.jrurstud.2014.04.003

Ní Laoire, C. (2000). Conceptualising Irish rural youth migration: A biographical approach. International Journal of Population Geography, 6(3), 229-243. doi:10.1002/1099$\underline{1220(200005 / 06) 6 \% 3 \mathrm{~A} 3<229 \% 3 \mathrm{~A} \% 3 \mathrm{AAID}-\mathrm{IJPG} 185>3.0 . \mathrm{CO} \% 3 \mathrm{~B} 2-\mathrm{R}}$

Norman, M. E., \& Power, N. G. (2015). Stuck between 'the rock' and a hard place: Rural crisis and re-imagining rural Newfoundland feminine subjectivities. Gender, Place \& Culture, 22(1), 50-66. doi:10.1080/0966369X.2013.855707

Petrin, R. A., Schafft, K. A., \& Meece, J. L. (2014). Educational sorting and residential aspirations among rural high school students: What are the contributions of schools and educators to rural brain drain? American Educational Research Journal, 51(2), 294-326. $\underline{\text { doi: } 10.3102 / 0002831214527493}$

Power, N. G., \& Norman, M. E. (2019). Re-inscribing gender relations through employment related geographical mobility: The case of Newfoundland youth in resource extraction. Canadian Journal of Sociology, 44(3), 283-308. doi:10.29173/cjs29599

Punch, S., \& Sugden, F. (2013). Work, education and out-migration among children and youth in upland Asia: Changing patterns of labour and ecological knowledge in an era of globalisation. Local Environment, 18(3), 255-270. doi:10.1080/13549839.2012.716410

Rauhut, D., \& Littke, H. (2016). 'A one way ticket to the city, please!' On young women leaving the Swedish peripheral region Västernorrland. Journal of Rural Studies, 43, 301-310. doi:10.1016/j.jrurstud.2015.05.003

Rosa, H. (2019). Resonance: A sociology of our relationship to the world. John Wiley \& Sons.

San Antonio, D. M. (2016). The complex decision-making processes of rural emerging adults: Counseling beyond dualism. Peabody Journal of Education, 91(2), 246-269. doi:10.1080/0161956X.2016.1151749

Saulnier, C. (2018). Working for a living, not living for work: Living wages in the Maritimes 2018 [Report]. Canadian Centre for Policy Alternatives. https://www.policyalternatives.ca/sites/default/files/uploads/publications/Nova\%20Scotia\%20 Office/2019/05/Living\%20wage $\% 20$ for\%20St $\% 20$ Johns.pdf

Saulnier, C. (2019). A living wage for St. John's, Newfoundland and Labrador [Report]. Canadian Centre for Policy Alternatives. https://www.policyalternatives.ca//publications/reports/living-wage-st-johns-newfoundlandand-labrador 
International Journal of Child, Youth and Family Studies (2021) 12(2): 25-47

Sherman, J., \& Sage, R. (2011). Sending off all your good treasures: Rural schools, brain-drain, and community survival in the wake of economic collapse. Journal of Research in Rural Education (Online), 26(11), 1.

Soderberg, S. (2014). Debtfare states and the poverty industry: Money, discipline and the surplus population. Routledge.

Statistics Canada. (2016). Census Profile, 2016 Census [New Brunswick, Newfoundland, Nova Scotia, Prince Edward Island]. https://www12.statcan.gc.ca/census-recensement/2016/dp$\mathrm{pd} /$ prof/index.cfm?Lang=E

Statistics Canada. (2020). Demographic estimates by age and sex, provinces and territories. https://www150.statcan.gc.ca/n1/pub/71-607-x/71-607-x2020018-eng.htm.

Theodori, A. E., \& Theodori, G. L. (2015). The influences of community attachment, sense of community, and educational aspirations upon the migration intentions of rural youth in Texas. Community Development, 46(4), 380-391. doi:10.1080/15575330.2015.1062035

Tran, K., \& Colman, R. (2008). Financial security and debt in Atlantic Canada. Report prepared for the Genuine Progress Index for Atlantic Canada. http://www.gpiatlantic.org/pdf/livstand/finsec.pdf

Williams, B. (2004). Debt for sale: A social history of the credit trap. University of Pennsylvania Press. 
International Journal of Child, Youth and Family Studies (2021) 12(2): 25-47

\section{Appendix}

Table 4. Descriptive Sample Statistics by Atlantic Canadian Provinces and Statistics Canada 2016 Census Data for Sampled Provinces

\begin{tabular}{lcccccccc}
\hline & $\begin{array}{c}\text { NB } \\
\text { Sample } \\
(\%)\end{array}$ & $\begin{array}{c}\text { NB } \\
\text { StatCan } \\
(\%)\end{array}$ & $\begin{array}{c}\text { SL } \\
\text { Sample } \\
(\%)\end{array}$ & $\begin{array}{c}\text { StatCan } \\
(\%)\end{array}$ & $\begin{array}{c}\text { NS } \\
\text { Sample } \\
(\%)\end{array}$ & $\begin{array}{c}\text { NS } \\
\text { StatCan } \\
(\%)\end{array}$ & $\begin{array}{c}\text { PEI } \\
\text { Sample } \\
(\%)\end{array}$ & $\begin{array}{c}\text { PEI } \\
\text { StCan } \\
(\%)\end{array}$ \\
\hline Employment Status & & & & & & & & \\
$\quad$ Employed & 49.85 & $54.70 \%$ & 46.82 & 49.50 & 43.29 & 55.20 & 41.27 & 58.20 \\
$\quad$ Unemployed & 12.61 & 11.20 & 10.98 & 15.60 & 9.71 & 10.00 & 4.76 & 12.30 \\
$\quad$ Retired & 37.54 & N/A & 42.20 & N/A & 47.00 & N/A & 53.97 & N/A \\
Gender & & & & & & & & \\
Male & 39.30 & 48.50 & 42.77 & 48.40 & 40.03 & 47.90 & 41.27 & 48.90 \\
Female & 60.70 & 51.40 & 57.23 & 51.50 & 59.97 & 52.10 & 59.73 & 51.10 \\
Age & & & & & & & & \\
15-24 & 4.69 & 12.50 & 4.62 & 12.20 & 2.29 & 13.50 & 3.17 & 14.20 \\
$25-29$ & 3.52 & 6.16 & 1.73 & 6.30 & 2.86 & 6.80 & 1.59 & 6.30 \\
$30-39$ & 12.32 & 13.40 & 9.25 & 13.50 & 6.57 & 13.00 & 7.94 & 13.20 \\
$40-49$ & 13.49 & 15.60 & 13.29 & 16.30 & 11.57 & 15.09 & 11.11 & 15.20 \\
$50-59$ & 19.06 & 19.01 & 23.12 & 19.10 & 20.00 & 19.10 & 12.70 & 18.70 \\
$60-69$ & 25.51 & 17.20 & 27.17 & 17.80 & 29.71 & 16.80 & 34.92 & 17.00 \\
$70-79$ & 16.72 & 9.50 & 16.76 & 9.60 & 20.00 & 9.50 & 15.87 & 9.40 \\
$80-89$ & 4.11 & 4.30 & 3.47 & 3.70 & 6.00 & 4.30 & 11.11 & 4.30 \\
Over 90 & 0.00 & 1.03 & 0.00 & 0.62 & 0.71 & 1.03 & 0.47 & 0.92 \\
\hline
\end{tabular}

Note. Sample data taken from Seeing a Future Dataset 2019. StatCan data from Statistics Canada Census Profiles (2016) New Brunswick, Newfoundland, Nova Scotia \& Prince Edward Island 
International Journal of Child, Youth and Family Studies (2021) 12(2): 25-47

Table 5. Descriptive Sample Statistics for Atlantic Canadian Region and Statistics Canada 2016 Census Data Averages for Region

\begin{tabular}{lcc}
\hline Variable & $\begin{array}{c}\text { Sample } \\
(\%)\end{array}$ & $\begin{array}{c}\text { Statcan } \\
(\%)\end{array}$ \\
\hline Gender & & \\
Male & 40.27 & 48.42 \\
$\quad$ Female & 59.73 & 51.52 \\
Employment Status & & \\
Employed & 45.42 & 54.40 \\
Unemployed & 10.42 & 12.27 \\
Retired & 44.08 & \\
Age & & \\
$16-24$ & 3.29 & 13.10 \\
$25-29$ & 2.82 & 6.39 \\
$30-39$ & 8.54 & 13.27 \\
$40-49$ & 12.29 & 15.54 \\
$50-59$ & 19.81 & 18.97 \\
$60-69$ & 28.50 & 17.20 \\
$70-79$ & 18.48 & 9.50 \\
$80-89$ & 5.40 & 4.15 \\
Over 90 & 0.47 & 2.92 \\
\hline
\end{tabular}

Note. Sample data taken from Seeing a Future Dataset 2019. StatCan data from Statistics Canada Census Profiles (2016). 